研

\title{
少量のアルミニゥムを含む鉊浴を利用した 鋼材のアルミナイジング
}

小松 登*・中村元志*・藤田浩紀*

\author{
Aluminizing of Steel by Means of Lead Bath \\ Containing a Small Amount of Aluminum \\ Noboru KOMATSU, Motoyuki NAKAYAMA and Hironori FUJITA
}

It was found that $\mathrm{Fe}-\mathrm{Al}$ alloy layers were formed on the surfaces of steel specimens, when the specimens were dipped in molten lead bath containing a liquid solution of $0.12 \sim 0.5 \mathrm{wt} \% \mathrm{Al}$ at $650 \sim$ $900^{\circ} \mathrm{C}$ for $5 \sim 60 \mathrm{~min}$.

The thickness of the alloy layer increased with the increase of aluminum content of the lead bath and with the rise of bath temperature.

The weight loss of steel specimens during dipping in a lead bath was much less than that dipped in an aluminum bath.

Metallographic observation and X-ray microanalysis revealed that the alloy layer formed in the lead-aluminum bath was composed of two layers as that formed in the aluminum bath. The layer adjacent to the steel was assumed to be $\mathrm{Fe}_{2} \mathrm{Al}_{5}$ and the outer layer was to be $\mathrm{FeAl}_{3}$.

A uniform cover of $\mathrm{Fe}-\mathrm{Al}$ alloy layer was observed on the surface of the steel specimens when they were dipped in $\mathrm{Pb}-20 \mathrm{wt} \% \mathrm{Sn}$ bath containing aluminum at a relatively low temperature of $600^{\circ} \mathrm{C}$ as that observed by dipping in a lead bath at $700^{\circ} \mathrm{C}$.

\section{1. ま えがき}

鋼に溶融アルミニウムメッキを施し，またはアルフィ ン法のごとく鉄材とアルミニウムを融着させる好理をす るさいに，鉛が種々の目的に利用されている ${ }^{1,2)}$ 。鉛の 融点が低い，またはアルミニウムと大きい比重差がある などの性質を利用している方法もあるが，アルミニウム メッキ層の厚サを薄くすることを目的とした方法も多 $W^{3,4)}$ 。この種の方法を使用する考え方の中に 鉛は鉄, またはアルミニウムと反応しないから，溶融鉛浴上にア ルミニウムを浮かし，この鉛浴中に鉄素材を浸セキして も鉄素材とアルミニウムは反応せず, アルミニウムメッ キは進行しないといら考えもあるように思われる。

たしかに溶融鉛は固体の鉄とはほとんど反応しないよ らである。しかし,アルミニウムは微量であるが溶融鉛中

* 豊田中央研究所 (愛知県名古屋市昭和区久方 2-12) TOYOTA Central Research and Development Lab., Inc.
に溶入し，たとえば純アルミニウムの融点に近い $660^{\circ} \mathrm{C}$ では約 $0.12 \% \mathrm{Al}, 770^{\circ} \mathrm{C}$ では約 $0.3 \% \mathrm{Al}, 900^{\circ} \mathrm{C}$ では約 $0.5 \% \mathrm{Al}$ 程度鉛中に溶入する5。。これを利用すれば溶融 鉛の表面にアルミニウムを浮かせた浴中に, 浸セキ保持 した鉄素材に Fe-Al 合金層を生成させ, 溶融アルミニウ ムメッキ被覆を作りらることが考学られる。(このさい, 表面に浮いたアルミニウムには鉄素材を一切ふれないよ らな操作を行なら。）これを実験的に確認し得たので， ここに報告する。

\section{2. 試料の調製および実験方法}

\section{2-1 試料の調製}

本実験に使用した鉄素材は $0.10 \% \mathrm{C}$ 以下の軟鋼で, その寸法は $3 \mathrm{~mm} \phi \times 40 \mathrm{~mm}$ である。前処理は\# 800 の エメリーペーパー研摩後, 2 〜 $3 \%$ パーコクリーナ水溶 液で脱脂した。また, 溶湯とのヌレを良くするため, $80^{\circ} \mathrm{C}$ に加熱した $5 \% \mathrm{NaF}+5 \% \mathrm{KCl}$ 水溶液中に $5 \mathrm{~min}$ 浸セキ後，ただちに熱風で乾燥した。浸セキ浴には純鉛 中に純アルミニウム $(99.75 \% \mathrm{Al}), \mathrm{JIS}$ アルミニウ 


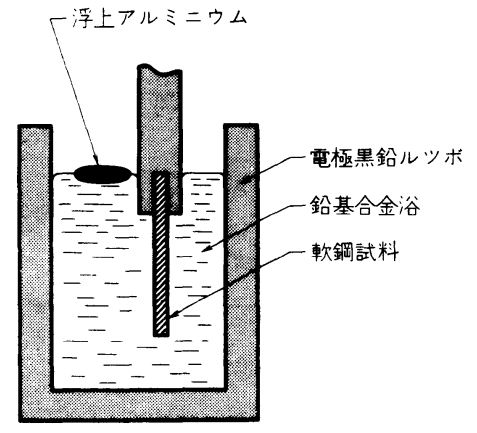

第 1 図軟鋼試料の浸セキ浴と浸セキ方法

厶合金鋳物 A C 2 B (3. $38 \% \mathrm{Cu}, 5.47 \% \mathrm{Si}, 0.28 \%$ $\mathrm{Fe})$ および AC $3 \mathrm{~A}(11.66 \% \mathrm{Si}, 0.21 \% \mathrm{Fe})$ をそれ ぞれ $2 \%$ 添加した浴と鉛中に $20 \% \mathrm{Sn}$ を添加し，これに $1 \% \mathrm{Al}$ を添加した 4 種類の鉛基合金浴を用いた。また, 比較のための浸セキ浴として鉛およびスズを含まない純 アルミニウム浴, AC 2 B 浴および AC 3 A 浴子併用 した。

\section{2-2 実験方法}

浴中への低炭素鋼の浸セキは第 1 図に示す方法で行な った。鉛基合金浴の場合は地金約 $1 \mathrm{~kg}$ を電極黒鉛ルッ ボ中に入れ，所定温度に到達後アルミニウムを添加し， 鉛浴中にアルミニウムを溶入させるため約 $30 \mathrm{~min}$ その温 度に保持後浮上しているアルミニウムと接触させないよ らに注意して，軟鋼を浸セキした。本実験に使用した最 高鉛浴温度の $900^{\circ} \mathrm{C}$ で, アルミニウムの溶解限が約 $0.5 \%$ であるが，鉛浴の酸化防止または軟鋼と合金層の生成な どによる，アルミニウムの消費を考虑して添加するアル ミニウムは約 $2 \%$ とした。軟鋼の浸セキ時間は，1６0 min，浸セキ温度は $540 \sim 900^{\circ} \mathrm{C}$ とし，浸セキ終了後浸 セキ時と同様の注意をして軟鋼を取り出した。

浸セキ後の試料は横断面について合金層形状を光学顕 微鏡で観察し，同時に顕微鏡に組み込んだスケールで合 金層の厚サを測定した。さらに浸セキ浴から取り出した ままの試料を，アンチモンを少量添加した濃塩酸を用い 表面付着物および合金属を溶解除去し，浸セキ前との 重量差を求めて素材軟鋼試料の浸食減量を測定した。合 金層の組成決定はX線マイクロフナライザーによって行 なった。通常の溶融アルミニウムメッキによって生成す る合金層と本実験で行なった方法によって生成する合金 層の性質を比較検討する目的で，アルミニウム基合金溶 湯中に，軟鋼を浸セキする実験も行なった。この場合， アルミニウム基合金浸セキ浴量を $400 \mathrm{~g}$ とし，\#2 黒鉛 ルツボを用いた以外は上記とまったく同様である。

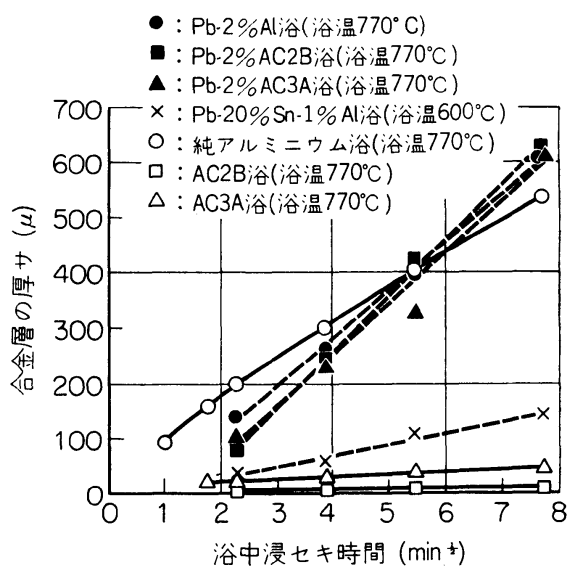

第 2 図各種浴中への軟鋼の浸セキ時間と 合金層厚サの関係

\section{3. 実 験 結 果}

第2图は $770^{\circ} \mathrm{C}$ の $\mathrm{Pb}-2 \% \mathrm{Al}$ 浴, $\mathrm{Pb}-2 \% \mathrm{AC} 2$ B浴および $\mathrm{Pb}-2 \% \mathrm{AC} 3 \mathrm{~A}$ と $600^{\circ} \mathrm{C}$ の $\mathrm{Pb}-20 \%, \mathrm{Sn}$ ー 1\% Al 浴と, 比較のために選んだ $770^{\circ}$ のの純アルミ ニウム浴，AC 2 B浴拈よびAC 3 A浴中に軟鋼を 1 〜 60min 浸セキしたときの試料表面に生成する合金層厚サ を示している。

4 種類の鉛基合金浴中で生成する合金層はいずれも浸 セキ時間が長くなるにつれて厚くなり, 浸セキ時間の平 方根とほぼ直線関係仙あるように思われる。また, $770^{\circ} \mathrm{C}$ の $\mathrm{Pb}-2 \% \mathrm{Al}, \mathrm{Pb}-2 \% \mathrm{AC} 2 \mathrm{~B}$ および $\mathrm{Pb}-2 \%$ AC 3 A浴中で生成する合金層の厚サはいずれも活とん ぞ大差はなくアルミニウム合金中の含有元素による合金 層厚サに差は認められなかった。 $600^{\circ} \mathrm{C} \mathrm{Pb}-20 \%, \mathrm{Sn}$ - $1 \% \mathrm{Al}$ 浴中で生成する合金層は反応温度が低いため, 当然著しく薄い。一方, 比較のため行なったアルミニウ ム基合金浴の場合には，たとえばアルミニウム浴中で生 成する合金層厚サのように浸セキ時間が短時間（1～ 5 $\min )$ の間は第 2 図 の中ではもっとも厚いが，長時間 浸セキするにつれてその增加量は少なくなる傾向がみら れ，AC 2 B 㧊よびAC 3 A浴中で生成する合金層厚サ は第 2 図中でもっとも薄く，浸セキ時間が長くなって もほとんど変化はない。

第3図には第2図とまったく同じ処理をした試料の 浸食減量を示した。このときの軟鋼の浸食減量は，4 種 類の鉛基合金浴中に浸セキした場合には，いずれも著し く少なくなっており，このときの減量はやはり浸セキ時 間の平方根に比較するようである。一方， 3 種類のアル ミニウム浴中での浸食減量は前者に比べ著しく多くなっ ている。 


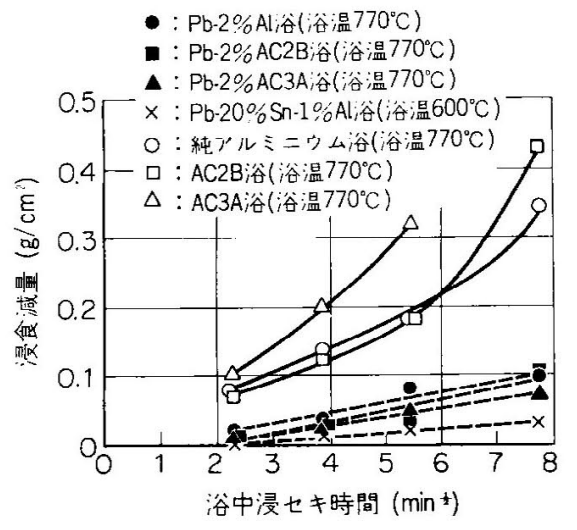

第3图各種浴中に軟鋼を浸七キしたとき の浸セキ時間と浸食減量の関係

第 4 図は浴温度を変化させた $\mathrm{Pb}-2 \% \mathrm{Al}$ 浴和よび $20 \% \mathrm{Sn}-1 \% \mathrm{Al}$ 浴中に, 軟鋼試料を $5 \mathrm{~min}$ 浸七キ L たときの合金層の生成の有無および生成した合金艒の厚 サを示している。 $\mathrm{Pb}-2 \% \mathrm{Al}$ 浴の場合には $680^{\circ} \mathrm{C}$ 以上 の浴温度にしなければ試料の全表面に均一な合金層が生 成しないが, $\mathrm{Pb}-20 \%, \mathrm{Sn}-1 \% \mathrm{Al}$ 浴を用いると, ルミニウムの融点以下の $600^{\circ} \mathrm{C}$ でも試料の全表面に均一 に合金層が生成することを示している。さらに，合金層 はいずれの浴でも温度が高いほど厚くなる傾向がみられ る。

第 5 图恰鉛浴中に溶入するアルミニウム量を变化させ たときに生成する, 合金層の厚サを調べた結果を示して いる。鉛浴中の溶入アルミニウム量はつぎのよらにして 変化させた。すなわち， $\mathrm{Pb}$-2％ Al浴をそれぞれ650, 700,770 および $900^{\circ} \mathrm{C}$ に保持し，アルミニウムをその 温度での溶解限まで入れる目的で浴を十分カクハン後, 浴の表面に分離し浖上したアルミニウムを完全に取り去

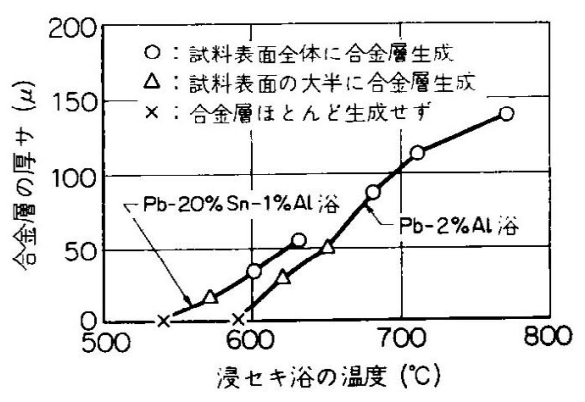

第 4 図 処理浴の温度と合金層厚サの関係

( 5 min 浸七キ)

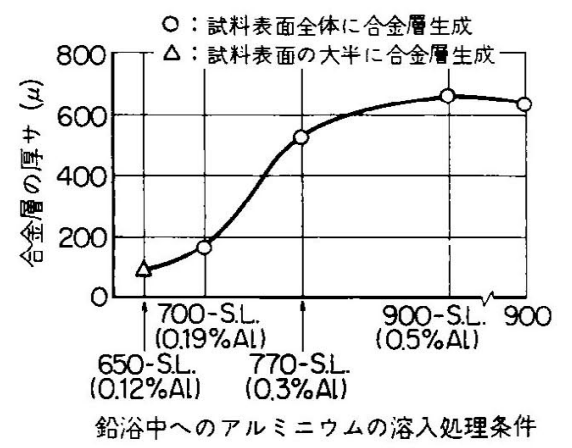

第 5 図 鉛浴中へのフルミニウムの溶入処理に よる合金層厚サの变化

(浴温 $900^{\circ} \mathrm{C}, 30 \mathrm{~min}$ 浸七キ)

った。このよらな操作を行なった場合には，鉛浴中への アルミニウムの溶入量は平衡状態図で示されるアルミニ ウム溶解限に相当する量と同じになると考えた。

第 5 図の横軸に示寸 650 -S. L., 700-S. L., 770S.L. 拈よび 900一S.L. はそれぞれ 650，700，770 お。 よび $900^{\circ} \mathrm{C}$ で上記処理をしたことを，また（）中に は状態図

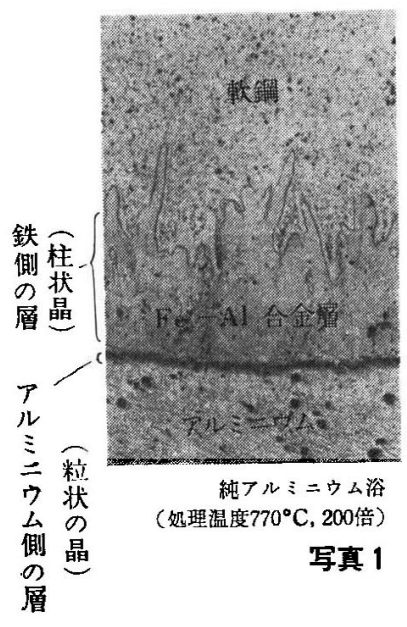

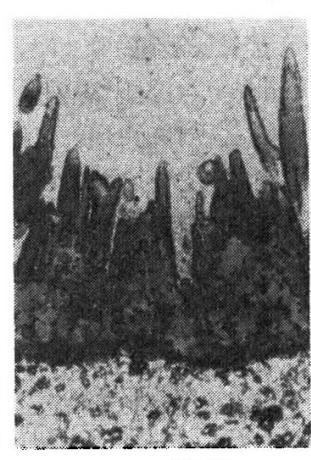

$\mathrm{Pb}-2 \% \mathrm{Al}$ 浴

(処理温度 $770^{\circ} \mathrm{C}, 200$ 倍)

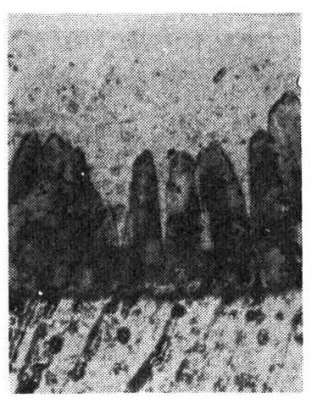

$\mathrm{Pb}-2 \% \mathrm{AC} 3 \mathrm{~A}$ 浴 (処理温度 $770^{\circ} \mathrm{C}, 200$ 倍)

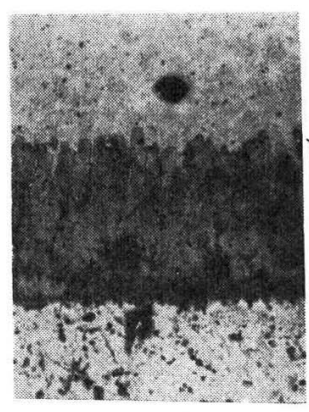

$\mathrm{Pb}-20 \%, \mathrm{Sn}-1 \% \mathrm{Al}$ 浴 (処理温度 $600^{\circ} \mathrm{C}, 200$ 倍)

各種浴中で生成した $\mathrm{Fe}-\mathrm{Al}$ 合金層の形状（30min 浸七キ）

\section{鉄 側 層状 晶 
いる。このようなオ法で溶入しているアルミニウム量を 変化させた鉛浴を，すべて $900^{\circ} \mathrm{C}$ に昇温し軟鋼を $30 \mathrm{~min}$ 浸七キしたときに生成する合金層は第 5 图に示す上らに 650-S. L.（浴中アルミニウム量が約0.12\% と考光られ る）では，軟鋼の一部分のみ合金層が生成し，その厚サ は約 $80 \mu$ である゙，770-S.L.（約0.3 w/o Al）では合 金層は陚料全面に生成し，穴のときの合金層の厚廿は約 $520 \mu$ あり，著しく厚サが增加している。しかし，900S. L.（約 $0.5 \mathrm{w} / \mathrm{o} \mathrm{Al}$ ）としても 770-S.L. の場合より 若干合金層は厚くなっているが，その増加量は少ない。 また，900ㄷ での溶解限以上にアルミニウムを添加した $\mathrm{Pb}-2 \% \mathrm{Al}$ 中で生成した合金層の厚サは 900-S. L. の場合と同程度である。

第 4 図から合金浴の温度が高いほうが層の厚サは大き

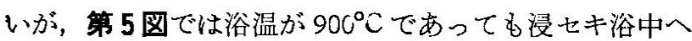
の溶入アルミニウム量が少ない場合には，合金層が薄い ことおよび末溶解の浮上アルミニウムは㬝厚サには影響 しないことがわかる。

写真1 Kは純アルミニウム浴および鉛基合金浴中に軟 鋼を $30 \mathrm{~min}$ 間浸七キしたときに生成する代表的な合金 層の形状を示している。770 $\mathrm{C}$ の純アルミニウム中で生 成した合金層は鉄側に突き出した層とアルミニウム側の 薄い層の 2 層よりなっており,著者らの結果礼によれば， 鉄側の層は $\mathrm{Fe}_{2} \mathrm{Al}_{5}$ の組成よりなる柱状晶であり，フ ルミニウム側の層は $\mathrm{Fe} \mathrm{Al}_{3}$ を主組成とする粒状晶であ った。 $\mathrm{Pb}-2 \% \mathrm{~A} 1$ 浴中で生成した合金層は純了ルミニ ウム浴中で生成した $\mathrm{Fe}$ - $\mathrm{Al}$ 合金㬝の形状とよく似て和 り，鉄側に突き出した不ぞろいの柱状晶とアルミニウム 側の薄い 2 層の層が存在している。また $\mathrm{Pb}-2 \% \mathrm{~A} \mathrm{C}$ $3 \mathrm{~A}$ 浴技よび $\mathrm{Pb}-20 \%, \mathrm{Sn}-1 \% \mathrm{Al}$ 浴中で生成した 合金層にも同様に 2 層存在 $\mathrm{L}, \mathrm{Pb}-2 \% \mathrm{AC} 3 \mathrm{~A}$ 浴中 で生成した合金層は $\mathrm{Pb}-2 \% \mathrm{Al}$ 浴中で生成した合金

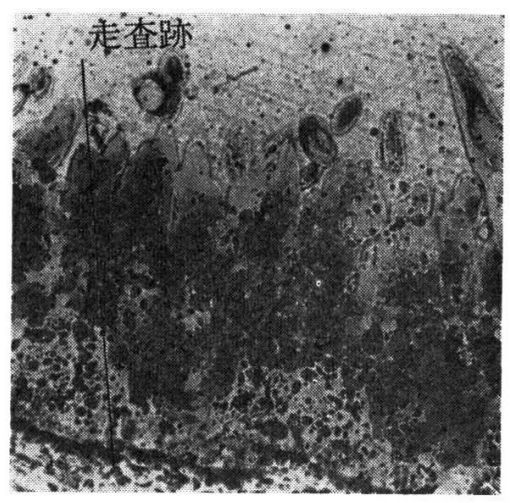

军真 2 X線マイクロアナライザーによる線分 析走查位置 $(\mathrm{Pb}-2 \% \mathrm{Al}$ 浴中生成合 金層）(200倍）

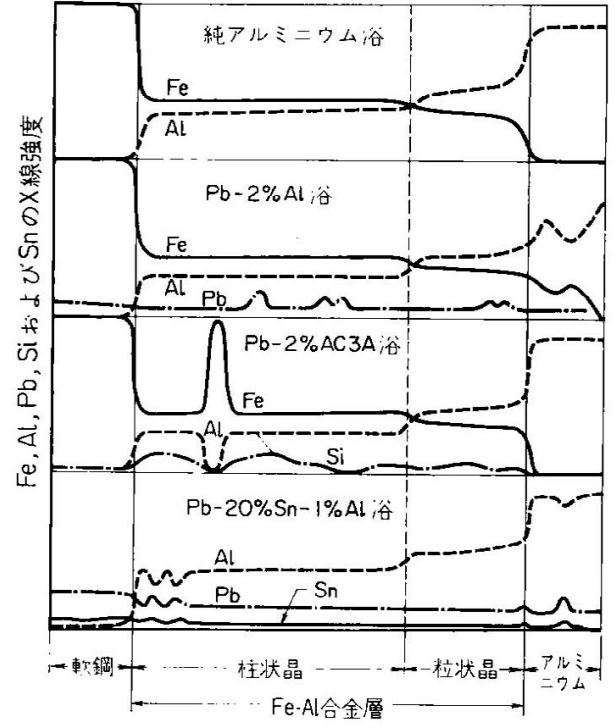

第 6 图合金層邛の元菜の濃度分布

層に似ているようである。 $\mathrm{Pb}-20 \% \mathrm{Sn}-1 \% \mathrm{Al}$ 浴中 で生成した合金凮では柱状晶の幅は, $\mathrm{Pb}-2 \% \mathrm{Al}$ 浴中 で生成した柱状晶の幅と等しいようであるが，その長サ はよくそろっている。しかし，純AC 3 A浴に浸セキし たときに生成する合金層の形状》とは著しく異なるよう に思われる。

第 6 図は純アルミニウム， $\mathrm{Pb}-2 \% \mathrm{Al}, \mathrm{Pb}-2 \%$,

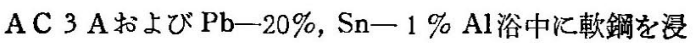
セキした後ただちに取り出し、アルミニウムで鋳包んだ 試料について合金層内の $\mathrm{Fe}, \mathrm{Al}, \mathrm{Pb}, \mathrm{Si}$ 抢上び $\mathrm{Sn} の$ 濃 度分布を調ベるため，X線マイクロアナライザーで線分 析した結果を示している。写真 2 おび写真了はそれぞ れ第6 図の $\mathrm{Pb}-2 \% \mathrm{Al}$ および $\mathrm{Pb}-2 \% \mathrm{AC} 3 \mathrm{~A}$ 浴

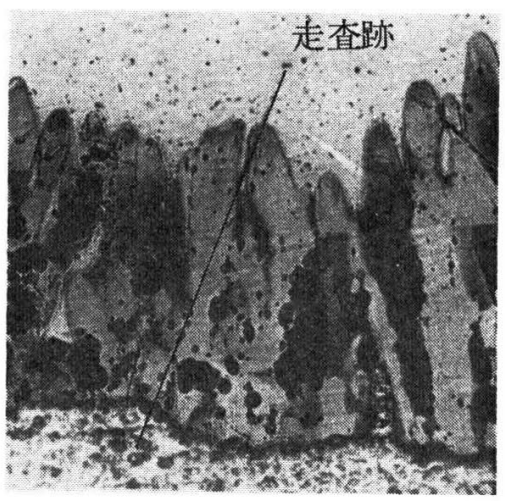

写真3 X線マイクロアナライザーによる線分 析走查位置 $(\mathrm{Pb}-2 \% \mathrm{AC} 3 \mathrm{~A}$ 浴中生 成合金層）（200偣） 
中で生成した合金層について，線分析したときのX線マ イクロアナライザー走査跡を示している。第 6 図から, 純アルミニウム浴中に浸セキしたときの合金層の場合に は， $\mathrm{Fe}$ は鉄素地之合金層の柱状晶部分で急激に減少し， 柱状晶中では濃度変化がほとんどなく，アルミニウム側 の層中では柱状晶中より若干少なくアルミニウム側に近 ずくにつれて，徐々に少なくなっていることがわかる。 一方, $\mathrm{Al}$ 量は $\mathrm{Fe}$ 量が增加すれば減少し, $\mathrm{Fe}$ 量が減少 するときには增加している。合金層中のこのような $\mathrm{Fe}$, Al 量の濃度变化は軟鋼を鉛基合金浴中に浸セキして得 た合金層中の $\mathrm{Fe}$ および $\mathrm{Al}$ の濃度変化と同じ傾向であ る。さらに，合金層のカタサが 鉄側では 約 Hv 900 1100，アルミニウム側では 約 Hv 500〜700 であること からも， $\mathrm{Pb}-2 \% \mathrm{Al}$ 浴中に軟鋼を浸セキしたときに得 られる合金層は, 純アルミニウム浴中で得られる合金層 とまったく同じで，鉄側の柱状晶は $\mathrm{Fe}_{2} \mathrm{Al}_{5}$, アルミニ ウム側の薄い層は, $\mathrm{FeAl}_{3}$ を主体とした層であると考兄 られる。な技， $\mathrm{Pb}-2 \% \mathrm{AC} 3 \mathrm{~A}$ 浴の場合には柱状晶 中で一部 $\mathrm{Fe}$ 量が著しく多く, 逆に $\mathrm{Al}$ 量が 少なくなっ ている部分は写真了に示すように，X線マイクロアナラ イザーの走査跡が一部鉄素地中にかかっているためであ る。同様に $\mathrm{Pb}-20 \%, \mathrm{Sn}-1 \% \mathrm{Al}$ 浴 の場合にも, 鉄 飞近い柱状晶に相当する部分で走查跡が鉄素地中にかか っていた。一方, 合金層中の $\mathrm{Pb}$ は検出感度を上げて測 定したが，微量の $\mathrm{Pb}$ がわずか点在するようであるが, その他の合金層中にはほとんど認められないように思わ れる。Si は第6图の $\mathrm{Pb}-2 \% \mathrm{AC} 3 \mathrm{~A}$ 浴の場合にみ られるように变動はあるが, 合金層中には約0.3〜1.75\% が存在していると考えられる。 $\mathrm{Sn}$ は $\mathrm{Pb}-20 \% \mathrm{Sn}-1 \%$ $\mathrm{A} 1$ 浴の場合にみられるように, $\mathrm{Pb}$ 分布と非常によく 一致しており，微量の $\mathrm{Pb}$ が存在する部分には $\mathrm{Sn}$ もわ ずか存在し，その他の部分では $\mathrm{Pb}$ 抢よび $\mathrm{Sn}$ はいずれ もほとんど存在してないように思われる。

\section{4. 考察}

溶融鉛中に $0.1 〜 2 \% \mathrm{Al}$ を添加し, 浮き上がってき たアルミニウムに直接接触しないよらに十分注意して, この鉛浴中に軟鋼を浸セキさせると軟鋼表面に合金層が できる。

この合金層は

1) 純アルミニウム浴中で軟鋼表面に生成した合金層 と形状がきわめて類似している。（写真 1)

2) カタサが鉄側で Hv 900〜 1100，アルミニウム側 で Hv 500 ～700 で純アルミニウム浴中生成する合金層 のカタサと良く一致する。

3）X線マイクロアナライザーの線分析結果(第 6 图) がやはり純アルミニウム浴中で生成する合金層のそれ6
と良く一致する。

これらの点から，純アルミニウム浴中で軟鋼表面に 生成する合金層と同じ合金層であり，鉄側の柱状晶は $\mathrm{Fe}_{2} \mathrm{Al}_{3}$ であり, 外側の薄い層が $\mathrm{FeAl}_{3}$ (十アルミニウム) の 2 層から成るといえる。したがって，この方法で作っ た合金層はアルミニウム浴中に浸セキして得たものとま ったく同様の用途に使用することが可能で，たとえば， 鋼材の耐熱性打よび耐食性を向上させるための被覆層 や，鋼材とアルミニウムを融着させるさいの接合相とし ても利用できる8 。

一方, $\mathrm{Pb}-\mathrm{Al}$ 浴中で生成した合金層の厚サは, 純ア ルミニウム浴中で生成した合金層の厚サとほぼ同程度で ある（第 2 図）にもかかわらず，鉄基合金浴に浸セキし たときの軟鋼の浸食量(浴中溶出鉄量十合金層中の鉄量) は純アルミニゥム浴での浸食量よりも著しく少ない（第 3 図）ことから，浴中への鉄の溶出量は $\mathrm{Pb}-\mathrm{Al}$ 浴では 著しく少ないことがわかる。

また, A C 2B浴 (Al一3.38\%, Cu一 $5.47 \% \mathrm{Si})$ およ び AC3A浴 (Al一11.66\% Si) への鉄の溶出量は純了 ルミニウム浴への溶出量よりも多く, アルミニウム合金 の組成成分に影響される7が，鉛に純アルミニウム， A C 2B および AC3A を添加した浴では, 軟鋼表面に 生成する合金層の厚サおよび浸食量はいずれの浴でも同 程度である（第 2 図，第3図）ことから，鉛浴への鉄の 溶出量は添加アルミニウムの組成成分に関係ないことが わかる。さらに, $600^{\circ} \mathrm{C}$ の $\mathrm{Pb}-20 \%, \mathrm{Sn}-1 \% \mathrm{Al}$ 合 金浴で生成する合金層の厚サおよび浸食量は $770^{\circ} \mathrm{C}$ の鉛 基合金浴の場合よりもいずれる少ないため, $\mathrm{Pb}-20 \%$, $\mathrm{Sn}-1 \% \mathrm{Al}$ 合金浴への鉄の溶出量も少ないように思 われる。したがって，鉛にアルミニウムを添加した浴に よって軟鋼にアルミニウム被覆を施すときは，以上に述 べたように通常のアルミニウム浴のごとく，鉄の溶入に より浸セキ浴が污染される程度が著しく少ないことが予 想される。さらに, $\mathrm{Pb}-20 \%, \mathrm{Sn}-1 \% \mathrm{Al}$ 浴を利用す れば浸セキ浴温度をアルミニウムの融点以下の $600^{\circ} \mathrm{C}$ 前 後にまで下げることが可能であるため，浴の污染をさら に減少し，かつ合金層の厚サを制御することが可能とな る。

\section{5. 結 論}

（1）鉛中にアルミニウムを溶入させた浴中に軟鋼を浸 セキするとアルミニウム浴中に浸セキした場合と同様に 軟鋼表面に $\mathrm{FeAl}_{3}, \mathrm{Fe}_{2} \mathrm{Al}_{5}$ からなる合金層が生成する と考えられ，一定の処理時間では鉛中溶入アルミニウム 量が多いほど，また浴温度が高いほど $\mathrm{Fe}-\mathrm{Al}$ 合金層は 厚くなった。

（2）鉛基合金浴を利用すると浸セキ温度を下げること 
が可能で， $\mathrm{Pb}-20 \% \mathrm{Sn}$ 合金浴の 場合にはアルミニウ

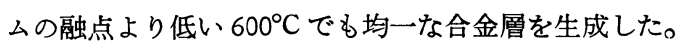

（3）鉛基合金浴でアルミニウム浸透処理を行なった場 合には，鋼材の処理浴への溶出はアルミニウム合金浴使 用の場合に比べて著しく少なく，したがって鉄污染も少 ない。

(1971-7-14 受理)

（昭和46年 5 月, 本協会第43回学術講演大会にて発表)

\section{引用 文 献}

1）楖野, 若林, 特許公報 昭38-18209
2）上原，特許公報 昭40-15326

3）長尾, 特許公報 昭39-18206

4) 勝山, 溶融アルミメッキ(日刊工業新聞 1963.9.25) p. 121

5) Hansen, Constitution of binary alloys, p. 122 (1958, McGRAW-HILL BOOK)

6）小松，中村, 藤田, 軽金属，18，9，467（1968）

7 ）小松, 中村, 藤田, 軽金属, 18，9，474（1968）

8）小松, 中村, 藤田, 特許公報, 昭44-6464

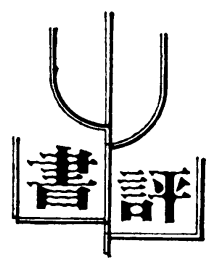

表面工学講座 2
表面工学講座第 1 巻「表面の構造」に続いて, 表面工 学講座第 2 巻「表面の一般的物性」が, 45 年 9 月 15 日に 発刊された。

物質の表面や界面の物理化学的性質は, 固体, 液体, 気体の接触できる界面の種類，およびそれからが巨視系 （平滑面）であるか，微粒子分散系であるかなどの界面 形態に関連してひじょらに重要であるのにるかかわら ず，その本態は必ずしも明らかでない。本書はそのらち 工学に関係の深いいくつかの基礎的性質を述べているる のであるが, とくに金属, 無機化合物, ポリマーその他 を含む有機物などの，主として固体や薄膜物質の巨視界 面についての一般的物性を論じている。本書では上記の 表面の特性のらち, 界面電気現象としては, 金属, 半導体, 電解質水溶液, 誘電体同志または相互の接触にさいして の電気的性質が述べられている。また, 固体の表面エネ ルギーや表面張力は表面のもっとも基礎的性 質である が, これらの性質は結晶表面の構造や結晶面への, 吸着 その他表面のすべての現象に関与する。これらは表面の 熱力学として一括して扱われている。固体面の光学的性 質に関しては界面での光の反射, 表面膜のスペクトル, 偏光, 流動視屈折, 光沢などの現象があげられるが, こ れらは固体表面や分散系の物理的, 化学的状態に強く支
配され，また逆に，それらの状態を知るための手段とし て用いられる。これらについても評述されている。内容 はつぎのようである。

第 1 章 表面熱力学

第 2 章 吸着膜および表面物性

2.1 吸着を支配する因子

2.2 吸着測定法

2.3 吸着膜の物性

第 3 章 界面電気現象

3.1 界面電気二重層

3.2 電子放出

3.3 表面隼位

3.4 界面動電現象

第 4 章 光学的物性

4.1 固体表面の光学的物性

4.2 散乱の光学

などの各項目を章として, 図, 写真, 表, グラフなどを たくさん盛りこみ, かつ関係の文献を豊富に引用して, 最新の知識を紹介している。このような点からも表面に たずさわる学生, 研究者, 技術者に参考となる書物であ る。

(後藤健一) 